\title{
STRATEGIES OF PT. PEGADAIAN TO ENHANCE MIKRO FIDUSIA SYARIAH CREDIT PERFORMANCE
}

\author{
Ning Karnawijaya* \\ Institut Agama Islam Negeri Surakarta
}

\begin{abstract}
This paper aims to find out the strategies of PT. Pegadaian as well as its effectiveness to enhance mikro fidusia syariah credit performance. It uses qualitative descriptive method through secondary data analysis of annual report PT. Pegadaian 2016-2017. Strategy is analyzed by qualitative data while its effectiveness is measured by quantitative data through comparison of Mikro Fidusia Syariah performance target and realization. The result shows that PT. Pegadaian strategies, such as product service channel reinforcement (collection), establishment sales force inorganic team, idle asset optimization, and establishment of Appraisal Officer Profession Certification Institution, have been implemented effectively to reach mikro fidusia syariah credit performance target 20162017. It is shown by customer number growth, number of transaction, sales turnover, outstanding loan, and mu'nah that exceed $100 \%$ in average. However, that strategy is less effective to maintain the achievement in 2017, its effectiveness is lower than 2016.
\end{abstract}

Keywords: Strategy; Pegadaian; Mikro Fidusia Syariah Credit.

\begin{abstract}
Abstrak
Artikel ini bertujuan untuk mengetahui strategi PT. Pegadaian serta efektivitasnya untuk meningkatkan kinerja kredit mikro fidusia syariah. Menggunakan metode deskriptif kualitatif melalui analisis data sekunder laporan tahunan PT. Pegadaian 2016-2017. Strategi dianalisis dengan data kualitatif sementara efektivitasnya diukur dengan data kuantitatif melalui perbandingan target dan realisasi kinerja Mikro Fidusia Syariah. Hasil penelitian menunjukkan bahwa PT. Strategi Pegadaian, seperti penguatan saluran layanan produk (penagihan), pembentukan tim anorganik tenaga penjualan, optimisasi aset menganggur, dan pembentukan Lembaga Sertifikasi Profesi Pejabat Penilai, telah diterapkan secara efektif untuk mencapai target kinerja kredit mikro fidusia syariah 20162017. Ini ditunjukkan oleh pertumbuhan jumlah pelanggan, jumlah transaksi, omset penjualan, pinjaman luar biasa, dan mu'nah yang melebihi rata-rata 100\%. Namun, strategi itu kurang efektif untuk mempertahankan pencapaian di 2017, efektivitasnya lebih rendah dari 2016.
\end{abstract}

Kata kunci: Strategi; Pegadaian; Kredit Mikro Fidusia Syariah. 


\section{INTRODUCTION}

Fiduciary industry is very potential to grow. Its product excellence, compare to bank and other financial service, is the main attraction for middle-low people as well as micro, small, medium enterprises (MSME). Implementation of OJK Regulation 31/POJK.05/2016 about fiduciary business provides an opportunity for private sector to do fiduciary business. In general, it arranges about legal entity, capital requirement, business requirement and business license procedures. It also sets about sharia business activities held by fiduciary or pawnshop. It sure drives the competition within fiduciary business.

Annual Report of PT. Pegadaian 2016 revealed that the issuance of POJK 31/POJK.05/2016 is a new stage for fiduciary industry in Indonesia. It is expected to support the escalation of financial inclusion for middle-low people and Micro, Small, and Medium Enterprise (MSME). Existence of well managed and good performance pawn business is believed to ease credit access outside banking industry.

Close competition, particularly in syariah fiduciary that has been flourished in the community, either conducted by Islamic bank or individual could decrease market share of PT. Pegadaian. PT. Pegadaian as a developing company has to face the competition; therefore it has to implement appropriate and effective strategy. PT. Pegadaian must provide the best service toward its customer in order to maintain its market share within the industry.

PT. Pegadaian needs strategies to enhance its business performance. Existence of Pegadaian Syariah as a strategic business unit (SBU) PT. Pegadaian becomes an integral part to face various business threats. Strategy is a process to determine company goals to accomplish its mission and as a stimulus for the company to determine its product, service, and market in the future (Morrisey, 1995). Its strategy is also imposed for the main service of Pegadaian Syariah, mikro fidusia syariah credit. Mikro fidusia credit syariah is a financing service for small micro business as a support to business expansion. A collateral use in this financing product is a Proof of Motorized Vehicle Ownership (BPKB) with fiduciary scheme 
guarantee agreement (rahn tasjily). There are two main products, Arrum and Amanah.

Strategy to improve performance is an important part to reach business success of Pegadaian Syariah. However, the strategy must be measured to know its effectiveness in reaching the goal. Effectiveness is an important concept to illustrate the organization success (Robbin, 2002). Measurement of strategy effectiveness is substantial in further policy and strategy determination.

Abubakar and Handayani (2017) said that development of fiduciary regulation aims to provide financing access to create financial inclusion with regard to community legal protection. Extension of pawn object can be done through sharia principle. Roikhan (2017) showed that during 2008-2014 Pegadaian Syariah reached 100\% efficiency. It such an optimism that Pegadaian Syariah asset will be increases along with inorganic action, such as merger, acquisition, spin off, or establishment of new company, which is stimuli variable in model structure combination. Policy scenario, that involving intervention variable in stimulated model structure variable, is the most ideal policy. The simulation result showed that the highest inorganic action the more optimal the increasing of Pegadaian Syariah asset within 10 years.

Ulbab (2016) found that marketing strategy used by Pegadaian Syariah Majapahit Branch Semarang is 4P strategy (product, price, place and promotion). Product strategy is showed by extension of ar-rahn product into Arrum (Ar-rahn for micro and small business) and appraisal optimization. Price strategy is showed by cutting down ijarah tariff. Place strategy implemented through opening UPC (Branch Services Unit). Promotion implemented by advertisement such as leaflet, brochure, souvenir, and publicity. Those strategies are effective to escalate customer numbers.

Ummah (2018) found that Arrum BPKP financiang in Pegadaian Syariah Sidoarjo branch goes well in accordance to Fatwa DSN-MUI 25/DSNMUI/III/2002. It could improve its customer micro business. However, determination of ujrah is not based on maintenance and safekeeping cost but on financing amount. Ula (2016) showed that customer satisfaction level toward 
services of Pegadaian Syariah is quite high (with score 77.26), while toward financing product is very high (with score 83.25). Besides, there is escalation of customer income after getting micro financing from Pegadaian Syariah.

Performance of micro fidusia syariah credit is also supported by the spirit to implement PT. Pegadaian mission, particularly to support economy condition of middle range people and MSME. Strategies implement by PT. Pegadaian in Mikro Fidusia Syariah credit are important to face tight business competition as well as to carry out that role. Therefore, this paper aims to do strategy analysis of PT. Pegadaian as well as measure its effectiveness in order to increase the performance of Mikro Fidusia Syariah credit.

\section{RESEARCH METHODS}

This research is qualitative descriptive research to analyze PT. Pegadaian strategy and its effectiveness to increase Mikro Fidusia Syariah credit performance during 2016-2017. This period is chosen due to the issuance of OJK Regulation No. 31/POJK.05/2016. Data used in this research is secondary data in the form of PT. Pegadaian Annual Report 2016-2017.

Data analysis used in this paper is descriptive qualitative analysis. Descriptive method is problem solving procedure through description of research subject/object based on the fact (Nawawi, 2001). Qualitative analysis is analysis using qualitative data, though there is quantitative data involved it states the fact. In other words, data used are quantitative but the analysis used is qualitative (Amir, Junaidi, Yulmardi, 2009). Therefore, analysis about strategy PT. Pegadaian is using qualitative data from PT. Pegadaian Annual Report. Furthermore, strategy effectiveness analysis is using quantitative data of target achievement of PT. Pegadaian in Mikro Fidusia Syariah credit sector. Robbin (2002) defined effectiveness as the as the level of objective achievement of the activities that have been carried out compared to the targets previously set. Effectiveness criteria used in this study is by comparing the targets previously set by PT. Pegadaian towards the realization of Mikro Syariah Fiduciary credit. Effectiveness measurement is the 
growth in the number of customers, the number of transactions, turnover, outstanding loans and mu'nah (capital rental income).

\section{RESULTS AND DISCUSSION}

\section{Pegadaian Strategy}

Strategy basically is planning and management to reach an objective. Strategy appears not only as map to show the direction but also show the operational tactics (Effendi, 2003). Strategy is a formulation of comprehensive planning on how the company will achieve its mission. Strategies will maximize competitive advantage and minimize competing limitations (Hunger and Wheelen, 2003). Strategy is the implementation of a method so that the company continues to grow, increase its profits, and compete within industry (Porter, 2002).

Based on PT. Pegadaian Annual Report 2016-2017, it showed that in 2016 company strategy in business development to enhance business performance was done carried out through improvement of customer service; create product variants, and service that caters customer needs, and increase fee-based business through optimizing technology and assets ownership. The main challenge in 2016 was the issuance of POJK No. 31 / POJK.05 / 2016 concerning fiduciary business. On the other side, the issuance of POJK further strengthened PT. Pegadaian commitment to continue supporting the government's efforts in developing a national economy based on populist economy in order to realize the nation's economic independence. But on the other hand, the business competition will be increasingly tight. Therefore, the focus of the Company's business development in 2016 is directed at improving customer based through services improvement.

In line with this strategy, the company continues to conduct business development in a focused and sustainable manner to increase and maintain market share. Pegadaian implements business diversification by developing three core services that support the company's vision, namely financing business, gold business and various services, including optimization of company assets. This is in line with the explanation of Abubakar (2012) that pawnshops in Indonesia were transformed from the beginning as public finance institutions, especially MSMEs, 
extending into institutions that also serve fiduciary, investment, shipping and receiving goods, safekeeping and buying and selling of precious metals. By implementing business diversification coupled with improved services, it is expected to increase sustainable business development and revenue.

Even though the sharia spin-off program had not been implemented in 2016, the development and expansion of sharia businesses was enhanced through channeling office programs. The office channeling program is intended as an expansion of the operational network of services for Islamic products that use conventional branch offices / outlets. The company also seeks to increase the market share of the sharia business through increasing sales activities, service improvements, and extracting competitive sharia funding sources.

In line with continuous efforts to improve performance, PT. Pegadaian must also enhance its strategic role to support the micro, small and medium enterprises (MSMEs) sector, which is the backbone of economic independence, through fiduciary-based microfinance services. In addition to develop Mikro Fidusia Syariah credit business, the company made improvements and development of Arrum's product features and expanded its market with the target of Arrum Haji. Furthermore, the company also refined its sales strategy by calculating the cost structure per product.

In 2017, competition level in fiduciary business was become tighter. The upcoming of new company, both which registered in OJK and still ran the business illegally. Each player collide strategy to win the customer's heart. Annual report of PT. Pegadaian in 2017 describes the strategic initiative that was performed. First, is strengthening product e-channel services (collection). Pegadaian develops information technology-based business processes to provide value added for service to customers. Through this strategic initiative, it is expected that it will be easier for customers to make payment and repayment transactions without having to transact at outlets, so they can reach more customers. Second, the formation of an inorganic sales force team. To face competition in the increasingly tight fiduciary industry, Pegadaian optimizes sales through the use of the Business Outsourcing process in the form of a sales force. With the sales force expected, the sales of Pegadaian 
products can be more targeted and reach all levels of society. Third, the optimization of idle assets to be more productive. Pegadaian counted its unproductive assets and optimized it. Fourth, is the establishment of an Appraisal Professional Certification Institute. Based on POJK No. 31 / POJK.05 / 2016, the fiduciary business has been open to the private sector so that professional estimators are needed. Hence, Pegadaian, as the largest and oldest fiduciary financial services institution in Indonesia, certainly has human resources who are experts in the field of collateral. Therefore, Pegadaian took the initiative to form an Appraisal Professional Certification Institute.

One of the main challenges in 2017 is services that have not been able to reach all of the existing market potential. The range and services provided by pawnshops are still limited. In the era of increasingly advanced technology, information technology-based services are needed. Therefore, Pegadaian launched a digital service called "Pegadaian Digital Service". In order to extend its services, PT. Pegadaian is involving the community to support its product marketing that called Pegadaian Agents. Pegadaian Agents will be an extension of Pegadaian in reaching untapped market potential so that more people will recognize Pegadaian services. Pegadaian Agent will get benefit in the form of fee based on the transaction obtained by the agent, so that there is a mutually beneficial relationship between Pegadaian and Pegadaian Agents.

Pegadaian continues to maintain and improves the reliability of information systems and technology, so that in terms of security, the quality and speed of service toward information management is getting better and more accurate. The application of a good Information Technology System is expected to provide direct support to the Company's operations in producing competitive products and excellent service to all stakeholders. The Development of Information Technology Systems at Pegadaian also pays attention to the development of technology and business where the direction of business has changed towards digital with the emergence of startup, fintech and the rapid development of the e-commerce market. For this reason, the Information Technology System at Pegadaian has also prepared the construction of a digital technology platform for application systems, security 
and infrastructure. This is carried so Pegadaian can penetrate the market to millennial customers by utilizing Pegadaian services through a digital system. The main strategy undertaken by Pegadaian is to implement the development of a distribution channel through Pegadaian Agents (agents of marketers and sales agents), to carry out transformation of digital-based products and services, to optimize Business Process Outsourcing (BPO) personnel to signify sales, conduct sustainable outlet arrangements in order to maximize utilization of the region's potential, optimize the supply of collateral warehouses in order to increase distribution channel capacity, and build information technology infrastructure to support the development of distribution channels and digital services.

Along with the company's main strategy, the business development strategy in order to improve the performance of the sharia fiduciary microcredit business is carried out by improving and developing the features of Arrum Products, expanding markets with Arrum Hajj targets, developing online features and Channeling, and expanding dealer cooperation for Amanah products. The company also refined its sales strategy by directly calculating cost structure and promotion.

\section{Effectiveness of PT. Pegadaian Strategy}

Handoko (2001) argues that effectiveness is the ability to choose the right destination to achieve the stated goals. Effectiveness shows the ability of a company to achieve precisely defined targets. Achievement of predetermined targets and applicable standards and standards reflect a company that has considered its effectiveness (Amirullah and Hanafi, 2002). Effectiveness is a very important concept in providing an overview of the success of an organization in achieving its goals. Effectiveness is carrying out activities that directly help the organization achieve several goals (Robbin, 2002). Effectiveness is a continuum that extends from effective, less effective, moderate, very less to ineffective. Effectiveness measures the extent to which organizational goals can be achieved to hit the goals to be achieved in an organization (Sigit, 2003). In this study, the effectiveness of PT. Pegadaian in improving the performance of sharia fiduciary microcredit is measured by comparing the target growth in the number of customers, the number 
of transactions, turnover, and outstanding loans against the realization of sharia fiduciary microcredit.

Pegadaian believes, the potential market is still quite large. Strategic initiatives will determine performance achievements. The performance targets in the sharia fiduciary microcredit business in this study include the number of customers, the number of transactions, turnover, outstanding loans, and mu'nah. The effectiveness of this study will be seen from the company's ability to achieve the set targets for sharia fiduciary microcredit which consists of Arrum and Amanah products.

Arrum Financing is Islamic finance for micro, small and medium entrepreneurs to get business capital with guaranteed BPKB and Gold. The vehicle remains with the owner so that it can be used to support the business. The financing period is $12,18,24$ and 36 months and can be repaid at any time. Arrum products in the sharia business include Gold Arrum (collateral in the form of Lantern Gold or jewelery), Arrum BPKB (vehicle BPKB guarantee for business people) and Arrum Haji (gold guarantee for registration of pilgrimage portions).

Amanah Financing is a financing intended for the purchase / ownership of new or used motorized vehicles in accordance with sharia principles for MSME employees and entrepreneurs. The basis for lending is by calculating repayment capacity determined on the basis of the amount of income / salary for permanent employees or based on business feasibility for small micro entrepreneurs. The pattern of collateral engagement is carried out with the rahn tasjily contract. Installment Period 12, 18, 24, 36, 48 and 60 months. The following table 1, table 2, and table 3 are data on the realization of the performance of sharia fiduciary micro credit PT. Pegadaian in 2016-2017. 
Table 1. Performance Growth 2016-2017

\begin{tabular}{llccc}
\hline \multirow{2}{*}{ Product } & \multicolumn{1}{c}{ Explanation } & $\mathbf{2 0 1 6}$ & $\mathbf{2 0 1 7}$ & Growth \\
\cline { 2 - 4 } Arrum & Number of Customer & 24.304 & 27.859 & $14,63 \%$ \\
& Number of Transaction & 26 & 39 & $50 \%$ \\
& Omzet & 536.107 & 784.131 & $46,26 \%$ \\
& Outstanding Loans & 386.416 & 627.46 & $62,38 \%$ \\
& Mu'nah & 62.830 & 113.176 & $80,13 \%$ \\
\multirow{5}{*}{ Amanah } & & & \\
& Number of Customer & 4.353 & 20.151 & $362,9 \%$ \\
& Number of Transaction & 4 & 20 & $400 \%$ \\
& Omzet & 103.240 & 461.580 & $347,09 \%$ \\
& Outstanding Loans & 99.519 & 443.686 & $345,83 \%$ \\
& Mu'nah & 10.009 & 43.174 & $331,35 \%$ \\
\hline
\end{tabular}

Source: Annual Report PT. Pegadaian tahun 2016-2017

Table 2. Performance Achievement 2016

\begin{tabular}{|c|c|c|c|c|}
\hline \multirow[b]{2}{*}{ Product } & \multirow[b]{2}{*}{ Explanation } & \multicolumn{3}{|c|}{2016} \\
\hline & & Target & Realization & Realization Achievement \\
\hline \multirow[t]{5}{*}{ Arrum } & Number of Customer & 18.164 & 24.304 & $133,80 \%$ \\
\hline & Number of Transaction & 20 & 26 & $130,00 \%$ \\
\hline & Omzet & 401.245 & 536.107 & $133.61 \%$ \\
\hline & Outstanding Loans & 303.973 & 386.416 & $127,12 \%$ \\
\hline & Mu'nah & 55.802 & 62.830 & $112,59 \%$ \\
\hline \multirow[t]{5}{*}{ Amanah } & Number of Customer & 3.382 & 4.353 & $128,71 \%$ \\
\hline & Number of Transaction & 4 & 4 & $100,00 \%$ \\
\hline & Omzet & 48.403 & 103.240 & $213.29 \%$ \\
\hline & Outstanding Loans & 46.993 & 99.519 & $211,78 \%$ \\
\hline & Mu'nah & 6.333 & 10.009 & $158,05 \%$ \\
\hline
\end{tabular}

Source: Annual Report PT. Pegadaian tahun 2016

Table 3. Performance Achievement 2017

\begin{tabular}{llccc}
\hline \multirow{2}{*}{ Produk } & \multicolumn{1}{c}{ Uraian } & Target & Realization & $\begin{array}{c}\text { Realization } \\
\text { Achievement }\end{array}$ \\
\cline { 3 - 5 } Arrum & Number of Customer & 49.547 & 27.859 & $56,23 \%$ \\
& Number of Transaction & 53 & 39 & $73,90 \%$ \\
& Omzet & 1.313 .055 & 784.131 & $59,72 \%$ \\
& Outstanding Loans & 832.352 & 627.46 & $75,38 \%$ \\
& Mu'nah & 111.553 & 113.176 & $101,46 \%$ \\
& & & \\
Amanah & Number of Customer & 13.047 & 20.151 & $154,45 \%$ \\
& Number of Transaction & 13 & 20 & $154,58 \%$ \\
& Omzet & 472.639 & 461.580 & $97,66 \%$ \\
& Outstanding Loans & 350.505 & 443.686 & $126,59 \%$ \\
& Mu'nah & 31.936 & 43.174 & $135,19 \%$ \\
\hline \multicolumn{2}{c}{ Source: Annual Report PT. Pegadaian tahun 2017} &
\end{tabular}

Source: Annual Report PT. Pegadaian tahun 2017 
Overall, table 1 shows sharia fiduciary micro-credit experiencing very significant growth. Table 2 and table 3 show the target achievements in 2016-2017 effective with the average achievement of the target number of customers, the number of transactions, turnover, outstanding loans and mu'nah (capital rental income) above $100 \%$. These results indicate that the strategy implemented by the company is quite effective in achieving the targets set. Taking into account the performance of sharia fiduciary microcredit which shows the achievement of targets in almost all indicators as described above, the company is optimistic that the sharia fiduciary micro credit segment still has promising prospects.

Based on annual targets achievement data in tables 2, shows that in 2016 the effectiveness of Ar-Rum products is effective with the average target number of customers, the number of transactions, turnover, outstanding loans and mu'nah above 100\%. While for 2017 (table 3) shows a decline in performance, even though the achievement has reached the target of $101.46 \%$ but the achievement level of the target number of customers, number of transactions, turnover and outstanding loans is only around $50 \%-75 \%$. This shows that the strategy for Ar-Rum products is less effective in 2017.

Performance achievements based on the achievement of the targets set for Amanah products show consistency in maintaining performance achievements. However, based on existing data despite the tremendous growth occurring in Amanah products, there was a slight decline in performance based on the target achievement in 2017 compared to 2016. Achievement of the 2016 target reached $128.71 \%$ of total customers, $100 \%$ of transactions, $213.29 \%$ turnover, $211.78 \%$ outstanding loans, and $158.05 \%$ returns. In 2017, there was a slight decrease with $154.45 \%$ of total customers, $154.58 \%$ of total transactions, $97.66 \%$ of turnover, $126.59 \%$ of outstanding loans, and $135.19 \%$ for mu'nah's.

Decrease in the performance of PT. Pegadaian in 2017 as indicated by the decline in target achievement compared to 2016 indicated that the strategy implemented by PT. Pegadaian has not been effective enough in maintaining the performance of sharia fiduciary microcredit. This is inseparable from the increasing competition in the Pegadaian industry. The increasing number of players in this 
industry is increasingly narrowing the market share of Pegadaian. The sharia business acceleration strategy is expected to be faster and more efficient by optimizing conventional outlets as office channeling to be reconsidered. Even though this strategy does not require additional overhead costs. However, based on previous research by Roikhan (2017) the need for inorganic action by PT. Pegadaian such as mergers, acquisitions and spin offs as well as the establishment of new companies can be stimulus and policy scenarios that include intervention variables in a combination of simulated model structures. The description of the strategy of PT. Pegadaian in 2016-2017 has not yet shown such inorganic action. However, Roikhan (2017), stated that the achievement of the most optimal escalation in Pegadaian Syariah asset value of Pegadaian Syariah as a Strategic Business Unit of PT. Pegadaian within 10 years still has an opportunity to be achieved.

The positive side of PT. Pegadaian strategy in maintaining market share and strength in maintaining a position as a market leader in the mortgage business needs to be supported by the ability to implement effective strategies. Targets that have been set for each product that are issued specifically for Arrum and Amanah products should be a concern. PT. Pegadaian should consider setting realistic targets amid increasingly fierce competition conditions. Hence, it does not create heavy burden but still realistic to continue to grow.

The right strategy in every development in the competition of the financial industry is a positive response from pawnshops to remain attractive to the market. Especially the strategy in dealing with the digital era that Pegadaian must inevitably follow as financial institutions. This will be a force for pawnshops to increase the market share of pawnshops. However, innovation and creativity in the use of digital media still need attention. Not only to improve service quality but also to expand market share.

Significant growth in 2017 on Amanah products is an important concern. One of the development strategies implemented is cooperation with dealers. As with Amanah's product features, this strategy certainly plays an important role in improving the performance of Amanah's products. Strategies like this can be 
considered to be applied to other pawnshops, but of course by taking into account the characteristics of each product. Therefore the established partnership structure can be more precise and effective.

Strategy effectiveness of PT. Pegadaian, especially in the sharia fiduciary microcredit segment with Arrum and Amanah products as indicated by the growth from year to year, is a positive indicator of the role of pawnshops in improving the economy of the community. With the easier access of the public to pawnshops products, it is expected to be able to build community interest in utilizing the products offered as an alternative economic solution for the community.

\section{CONCLUSION}

The faster the fiduciary industry development and the tighter the competition forces PT. Pegadaian to implement appropriate and effective strategy. Mikro Fidusia Syariah credit is a segment that becomes integral part of PT. Pegadaian to grow and thrive. Pegadaian attempts to establish strategies to enhance its performance in accordance to extension of customer need and economy condition. Those strategies are enrichment features of its main product (Ar Rum and Amanah), reinforcement of e-channel product service (collection), establishment sales force inorganic team, idle asset optimization, and establishment of Appraisal Officer Profession Certification Institution.

Based on 2017-2017 data, it showed that strategies applied by PT. Pegadaian were effective enough to achieve Mikro Fidusia Syariah credit target. It shown through average of realization over target performance is above $100 \%$. However, those strategies were less effective to maintain working performance in 2017, whereby the effectiveness was decreased. Those might be caused by the tighter the competition within industry as well as the higher target set by PT. Pegadaian in 2017. 


\section{REFERENCES}

Abubakar, L dan T. Handayani. 2017. Telaah Yuridis Perkembangan Regulasi Dan Usaha Pergadaian Sebagai Pranata Jaminan Kebendaan, Jurnal Mulia Hukum, 2 (1): 80-92

Abubakar, L. 2012. Pranata Gadai Sebagai Alternatif Pembiayaan Berbasis Kekuatan Sendiri (Gagasan Pembentukan UU Pergadaian), Jurnal Mimbar Hukum Fakultas Hukum UGM, Vol. 24

Amir, Junaidi dan Yulmardi. 2009. Metode penelitian Ekonomi dan Penerapannya. IPB Press. Bogor

Amirullah, H. R. 2002. Pengantar Manajemen. Graha Ilmu. Yogyakarta

Effendy. 2003. Ilmu Teori dan Filsafat Komunikasi. Citra Aditya Bakti. Bandung

Handoko, T. H. 2001. Manajemen. BPFE. Yogyakarta

Hunger, J. D dan Wheelen L.T. 2003. Manajemen Strategis diterjemahkan oleh Julianto Agung S. Andi Publisher. Yogyakarta:

Laporan Tahunan PT. Pegadaian. 2016. Berkomitmen pada Ekonomi Kerakyatan untuk Mewujudkan Asa Bangsa

Laporan Tahunan PT. Pegadaian. 2017. Semakin Muda(h)

Morrisey, G.L. 1995. A Guide to Strategic Thinking:Building Your Planning Foundation. Jossey-Bass. San Fransisco

Nawawi. 2001. Metode Penelitian Bidang Sosial. Gadjah Mada University Press. Yogyakarta

Porter, M. E. 2002. Strategi Bersaing Teknis Menganalisis Industri dan Pesaing. Erlangga. Jakarta

Robbin, S. P. 2002. Prinsip-prinsip Perilaku Organisasi. Erlangga. Jakarta

Roikhan. 2017. Efisiensi Pegadaian Syariah dan Prospek Pertumbuhan Aset di Indonesia, al-Uqud: Journal of Islamic Economics . 1(1): 59-82

Sigit, S. 2003. Esensi Perilaku Organisasi. Penerbit Lukman Offset. Yogyakarta

Ula, A.M. 2016. Tingkat Kepuasan Nasabah Terhadap Pelayanan dan Produk Pembiayaan Mikro di Pegadaian Syariah. Skripsi. Fakultas Syariah dan Hukum UIN Syarif Hidayatullah. Jakarta 
84 Al-Uqud: Journal of Islamic Economics

Volume 3 Nomor 1, Januari 2019

Ulbab, N. 2016. Strategi Pemasaran Produk-Produk Gadai Syariah Dalam Meningkatkan Jumlah Nasabah (Studi Kasus di Pegadaian Syariah Cabang Majapahit Semarang), Skripsi, Fakultas Ekonomi Dan Bisnis Islam UIN Walisongo. Semarang

Ummah, F.S. 2018. Analisis Produk Pembiayaan Arrum BPKB dalam Meningkatkan Usaha Mikro Nasabah Pegadaian Syariah Kantor Cabang Sidoarjo. Skripsi. Fakultas Ekonomi Dan Bisnis UIN Sunan Ampel. Surabaya 